\title{
The Role of Recruitment and Selection Practices in the Organizational Performance of Iraqi Oil and Gas Sector: A Brief Literature Review
}

\author{
Ali Kadhim Saddam ${ }^{1,2} \&$ Nur Naha abu Mansor ${ }^{1}$ \\ ${ }^{1}$ Department of Human Resource Development, Faculty of Management, Universiti Teknologi Malaysia, Skudai, \\ Johor Bahru, Malaysia \\ ${ }^{2}$ Department of Business Administration, Collage of Business and Economic, Missan University, Missan, Iraq \\ Correspondence: Ali Kadhim Saddam, Department of Human Resource Development, Faculty of Management, \\ Universiti Teknologi Malaysia, Skudai, Johor Bahru, 81310, Malaysia. E-mail: alialaraqi_69@yahoo.com
}

Received: April 5, 2015 Accepted: May 20, $2015 \quad$ Online Published: August 20, 2015

doi:10.5539/res.v7n11p348 URL: http://dx.doi.org/10.5539/res.v7n11p348

\begin{abstract}
Oil and gas sector forms the backbone of Iraqi economy with more than 80 percent of all businesses in Iraq related to oil and gas. The sector also employs a bulk of the workforce, playing a crucial part in economic and social development in Iraq. Therefore, the health of this vital sector is very important to up keep the health of the overall economy. However, for the past two decades, this sector has shown a sluggish growth and performance in achieving the expected goals. Many businesses seem to have gone out of business due to various reasons but mainly due to lack of competent workforce. The firms entering into businesses are much less as compared to firms going out of business. One of the reasons for the high rate of business failures among oil \& gas sector is due to its lack of attention on the human resource aspects. Therefore, the broader objective of this study is to review the role of Strategic Human Resource Management (SHRM) practices in oil \& gas related firms in Iraq. Specifically, this study attempts to review the relationship between recruiting and selection practices and firm performance in oil \& gas sector Search depends in test hypotheses on the theoretical analysis in the study of the relationship between recruitment and selection and organizational performance in the Iraqi oil and gas sector. Based on the literature review, a strong relationship between recruitment $\&$ selection and firm performance of oil and gas sector in Iraq is found. Therefore, the researchers hereby recommends future research in the field of study to deeply look into the role HRM practices in iraqi oil and gas sector.
\end{abstract}

Keywords: organizational performance, labour productivity, customer satisfaction, organizational innovation, product quality, recruitment and selection, oil \& gas, Iraq

\section{Introduction}

Oil and Gas sector forms the backbone of Iraqi economy and have been playing a crucial part in economic and social development in Iraq. The crucial role of this sector in the economic and social development of Iraq can be seen from the fact that 94 percent of all enterprises and accounting for 75 percent of all employment are related to oil \& gas (UIA, 2013). Although, most people are familiar with large oil companies, such as Iraq National Oil Company, Iraq Petroleum Company, and Iraqi Oil Tankers Company, etc., it is the oil sector that drives Iraqi economy. Therefore, the health of this vital sub-sector is very important to up keep the health of the overall Iraqi economy. Although, the relative importance as a share of the number of enterprises and the number of employees is declining as compared to the situation at the beginning of the 2000s, there is no change in the fact that the sector still accounts for the vast majority of enterprises and employees in Iraq. Many of the large oil companies, such as Iraq National Oil Company, Iraq Petroleum Company, and Iraqi Oil Tankers Company began as small family businesses (Al-Sabah, 2007) and turned into mega corporations. The resurgence of oil sector would not only encourage competition in the market and but can be the thrust in making new industries and translating the existing industrial structure.

Most of the products of the sector are made up of crude oil products made by firm subcontractors, and hence, the availability and reliability of Iraqi products is backed by the fundamental strength of oil sector. Local economies are supported by the activities of the firms especially those which are involved in the service industry, the retail industry, and the construction industry helping to revitalize the local economy and increasing employment opportunities (Al-Sabah, 2007). Since the oil sector has been driving the economic growth, the last decade has 
seen a sluggish growth in the oil sector. Further, the profitability and investment of oil firms have not increased significantly and the entry of new businesses in the sector has been on the decline. The main reason for such a state of affairs of Iraqi oil \& gas sector is attributed to severe lack of investment, poor management, lack of skilled human resources and destruction of infrastructure due to two decades of war and sanctions (Hanna et al., 2014). The Iraqi government has made the oil production contracts with various multinational companies. The principal element behind this seems to be the trend in performance, which explicate a big number of enterprises. This development, however, should not be regarded entirely as a problem of performance because they have the potential to grow and employ more people or companies. To meet the timetable, Iraq has been facing many challenges. Iraqi refining and export, both infrastructures are at bottlenecks, which are supposed to be upgraded so that they can process much more oil. In Southern Iraq, oil exporters are utilizing their full capacities, whereas in North Iraq, the export capacity has been restricted, which needs to be expanded.

Nevertheless, productive business management of firms mostly relies upon the quality of human resource that supports companies (Anthony et al., 2002). Abundant studies exist that the significant relationship between human resource management practices and organizational performance. (e.g. Guest, 2002; Wright et al., 2003; Tessama \& Soeters, 2006; Quresh et al.,2010; Chen and Huang, 2009; Lorg et al., 2013; Tangthorg et al., 2014). To secure and train the high quality personnel is fundamental factor for firms' growth, which frequently has specified opportunities to employ managerial resources. But, it is argued that small firms pay less attention to human resource management (HRM) practices as compared to large enterprises (Kok, 2003; Wong, Marshall, Alderman, \& Thwaites, 1997). Therefore, the prime objective of this study is to develop and test a conceptual model linking recruitment and selection function to firm performance that fit oil sector firms. This study specifically, attempts to examine the relationship of selection and recruitment practices with firm performance. Lynch and Smith (2010) is the recruitment and selection process for the initial evaluation of staff. This is concerned with identifying and attracting and selecting the right person to meet the needs of the organization of human resources. It is an important process for the implementation of business performance, the results of the recruitment and selection of appropriate help the organization in achieving its goals. According to Qureshi and Ramay (2006) HR practices in the recruitment and selection associated positively with the employee's performance while training is the most factor impact performance of the organization from other practices.

Marquez (2007) Post HRM in the recruitment process helps to enhance the knowledge of the workforce and the skills required. It is also useful to know to raise the level of staff skill requirements.

\section{Literature Review}

\subsection{Role of HRM in Organizations}

HRM as an organizational function focuses on effective and efficient utilization of the human resources through recruitment, management and providing direction to the employees to achieve organizational objectives (Opatha, 2010). This indicates that HRM is responsible for attracting and selecting appropriate workforce, providing them with the training to enhance their capabilities, assessing their performance and rewarding them for their performance in achieving organizational goals. Organizational objectives are dependent upon the productivity of employees as Stone (2005) highlights that HRM is concerned with the productive use of people in the organization to achieve desired objectives. The effective use of HRM practices would not only enhance organizational performance but would also help in managing the human resources more effectively (Farnham, 2010). In order to accurately measure human resource practices, a number of HR functions may need to be evaluated. However, the importance and priority of such practices differ across firms depending upon their circumstances and resource availability.

Reservations have been expressed about the concept of HRM by many academics mainly due to the fact that there is no universally agreed upon concept of HRM or the practices it involves. Researchers agree that bundle of mutually compatible HR practices have a positive effect on organizational performance (Farnham, 2010; Lengnick-Hall et al., 2009). The most widely used practices that are normally followed by firms are related to recruitment and selection, training and development, performance evaluation and compensation (Dessler, 2008; Fisher, Schoenfeldt, \& Shaw, 2006).

The key to survive in today's business is to properly manage the human resources of the company. The efficiency of a firm (Huselid, 1995; Terpstra \& Rozell, 1993) and its capability to construct a sustainable advantage to compete (Pfeffer, 1994; Prahalad, 1983) may depend upon whether the practices related to HRM are successfully and properly implemented (Jackson et al., 2003; Adnan \& Izzat, 2012). A company's human potentials are very hard to duplicate than duplicating equipment, plant and any product (Flanagan \& Despanade, 1996). Accordingly, existence of a company in the industry may depend upon the well being of its employees. 
The research shows that insufficient and inadequate management of employees in a company has ensued in high turnover rates and low productivity (Mathis \& Jackson, 1991) and is an important cause of business failure (McEvoy, 1984). The generic purpose of HRM is to generate and retain an appropriate and contended workforce who gives the maximum contribution to the organizational success (Opatha, 2010).

Therefore, a motivated, highly qualified and happy staff is the main factor for the success of firms. And also, an effective HRM system helps organization attract and hire suitably qualified people and keep their knowledge, skills and attitudes updated. Therefore, they become capable of performing what they are supposed to perform. On the other hand, an effective HRM system helps the organization to retain a contended work force. It means that the HRM system helps keep employees motivated (Lockwood, 2007). A motivated workforce brings many benefits to the firm. For example, if the work force is happy, they always give their maximum contribution to the organization by means of producing quality products or services. If the product or service is good in terms of its quality, customers buy these products or service and are satisfied. Services lead to co-creation of value based on the competencies of the company and customers (Vargo \& Lusch, 2008). A long-term and sustainable competitive advantage can be attained through customer service yielding customer satisfaction (Gebauer et al., 2011). In the short run, it will be difficult to duplicate this service, and will be surpassed by the competitors. Any good service cannot reach quickly; it may take months of investing in training and sincere dedication to accomplish it.

It is suggested by the research that customers are well satisfied with a company they raise their firm loyalty which results in reducing price elasticity, lowering market costs, and decreasing transaction costs, thereby improving overall financial performance (Tarasi et al., 2013). Nevertheless, firms may rely upon their employees to enhance customer satisfaction. Particularly, dealing with this issue, literature pertaining to management discovers a direct linkage between attitudes of employees and customer satisfaction (Evanschitzky et al., 2012; Jeon \& Choi, 2012). Better interactions are provided by employees to the customers when they are well satisfied with the firm. Drawing upon these findings, it is intuitive to understand that employees play a crucial part in their organizations and are able to decide even the fate of the organization. Therefore, the organization should ensure that they have got the right people with right skills at the right time for the right jobs in right numbers. In order to fulfill these requirements, the intensification of recruitment and selection function of the business has a lot to do with.

Hanna et al. (2014) in their study on foreign direct investment in Iraqi oil and electricity sectors has highlighted that there is dearth of qualified and skilled human capital which is needed for the development of the sector and the country. In its report, World Bank (2006) highlighted that Iraq needs to strengthen its labor market conditions that require massive retraining programs and incentive schemes to build and encourage the private sector to play its role in the development of the country. The report further highlights that the Iraqi public sector, which is the biggest employer in the country needs to adjust its wage according to the productivity rather than on education and number of years of service. Furthermore, recruitment to public sector jobs must be based on appraisal of future performance. Hendrix (2013) has also highlighted that for Iraq to develop and be competitive it requires skilled human resources that are well trained in various areas such as finance, project management, human resources, information technology, strategic planning and leadership etc.

\subsection{Recruitment and Selection Practices in Organizations}

Recruitment and selection are vital functions of human resource management for any type of business organization. These are terms that refer to the process of attracting and choosing candidates for employment. The quality of the human resource the firm has heavily depends on the effectiveness of these two functions. Selecting and recruiting the wrong candidates who are not capable of fitting in the culture of an organization may not be cost effective strategy. Within an oil and gas sector, the purpose of selection and recruitment is to get the efficient and dedicated employees that help achieving the objectives of an organization at the lowest cost (Ofori \& Aryeetey, 2011).

Recruitment is the process of finding and appealing suitably qualified people to apply for job vacancies in the organization (Opatha, 2010). It is a set of activities an organization uses to attract job candidates who have the needed abilities and attitudes. Recruitment is the process of generating a pool of qualified applicants for organizational job vacancies. According to Ofori and Aryeetey (2011), recruitment is the procedure of generating competent individuals' pool to apply for employment within an organization. The general purpose of recruitment is to provide the organization with a pool of potentially qualified job candidates. The quality of human resource in an organization highly depends on the quality of applicants attracted because organization is going to select employees from those who were attracted. Recruitment is an entrance of human capital into an organization 
(Henry \& Temtime, 2009). In order to make sure, an organization must follow the steps to monitor that they have inducted the right individuals who can fit in their environment to achieve the goals (Henry \& Temtime, 2009).

Barber et al. (1999) in their research of 171 U.S firms found that most of the recruitment practices rely on referrals and advertising. They found that there were few organizations which had formal brochures available for applicants. Cassell et al. (2002) found that the referrals played effective role in hiring employees. They already had some dedication to the organization and the manager/owner was able to discover some information before the new employee started. Word of mouth has no financial outlay which is very beneficial for firms as they often suffer from resource scarcity and is also considered as an effective method of recruitment (Greenidge et al., 2012). Selection is the process of making the choice of the most suitable applicant from the pool of applicants recruited to fill the relevant job vacancy (Opatha, 2010). According to Ofori and Aryeetey (2011), selection is a procedure in which particular instruments are utilized to select the best people from the pool of individuals that are suitable for the jobs. Selection involves the use of one or more methods to assess applicant's suitability in order to make the correct selection decision. Selection can be alternatively seen as a process of rejection as it rejects a number of applicants and select only a few applicants to fill the vacancy. Thus, selection function may be a negative function rather than a positive function. The objectives of selection function are to get the right person to the right job, establish and maintain a good image as a good employer, and maintain the selection process as cost effective as possible.

As explained by Henry and Temtime (2009) to fill an available vacancy, selection is a systematic procedure of decisions about an individual. During this process, it is very important to consider about a firm for a numerous reasons. According to Henry and Temtime (2009), firm's performance usually relates to the people who work in it, meaning firm needs to hire those people whose objectives and ambition matches with the firm. Similarly, hiring someone new is also an expensive process for an organization. Henry and Temtime (2009) highlights that hiring a new individual might be a difficult job, but ultimately it will benefit the organization. It has been argued by Priyanath (2006), hiring someone with the correct and required qualifications is a challenging task. He further explains that the problem increases when there is deficiency of systematic method for selecting and recruiting new people. A systematic recruitment procedure requires identification of vacancies, analysis of job, description of job, specification of a person and advertising. It also requires process of recruitment, gathering information, evaluation of qualifications and making decisions about employing someone.

Odiorne (1984) indicated that hiring practices depends on quality of the contender in the organization and the nature of the selection phase of relative effectiveness depends on attracting talented candidates. Smith et al. (1989) argued that when the effective recruitment phase is performed, the definite assortment procedure becomes less important. When an organization hires to fill existing vacancies, the decision in the first stage of this process includes the detailed analysis done by the human resource management through different evaluations and looking at different technical and administrative skills. This may have been through the planning process of human resources especially in recruitment which is relatively common occurrence.

According to Odiorne (1984), actual recruitment and assortment is the result of reduced morale and good labor mobility. Recruitment is expensive so ineffective or poor recruits may not work well and/or leave their jobs, so the need for greater engagement. Hiring practices among national studies show that in fact, recruitment involves petite or no effort to authenticate the approach. Workers often rely on line manager's response and probation and disciplinary procedures to clear the error. The company has higher quit rates of smoking and they lived together, and often in their hiring practices, they do not scrutinize their structure of job. Modern trainings obligated that certain approaches are extra effective than hiring someone else to calculate the value of employee engagement.

Miyake (2002) indicated that through advertising or commonly job candidates occasionally enlisted over word of mouth by prevailing employees. Besides being cheap, "vine" that employees who stay longer (voluntary turnover low), which is less likely to be fired (low involuntary separations). People employed by word of mouth stay lengthier as they have a stronger awareness of what the job actually contains. It was claimed that individuals who were recommended by other workers were good and more convincingly knowledgeable about the job than persons who practically go over correspondents and agencies. Burack (1985) argues that staffing bases are knowingly related to alterations in workers performance, turnover, gratification and organizational promise. In a study of 201 large U.S companies, Burack asked respondents to rate the efficiency of nine employment bases in yielding high superiority, high execution workers. The three top hierarchical practicalities were employee recommendations, university employing and executive hunt companies. Though, Burack (1985) cautions that although these overall results are valuable, there is a necessity for better internal scrutiny of the relative excellence of workers produced by different foundations. 
In measuring the employment of new graduates, Kersley et al. (1997) reiterated the preventive socialization phase for student's preparing to enter occupations and in specific the effects of staffing and assortment experiences on career prospects and orientation. They highlighted that the nature of the search movement of student work will be with the relevant work knowledge and contact with bosses over recruitment activities. By understanding employer's job search activities and literature and recruiting events, student goals, values, environment and work practices, organizations gather information that guide the final decision-making. Delery and Doty (1996) claimed that to provide individual's with knowledge of employment chances, and equip them with skills to take the initiative to approach potential employers, will lead to more effective career and selection process. There is also evidence that employers prefer graduates with a broader range of skills and a greater appreciation of not only theoretical knowledge but also of business needs.

While the proficiency of contender is determined by the employment process, the assortment/selection decision is a tough one. Gould (1984) contends that most of the errors in recruitment are caused by the fact that manager's often give little thought in decision-making. Employers are surprised and disappointed when the reservation fails, and often point fingers to the person taking decision, rather than admit the weakness of the process and methods, even the soundness of technologies and best practices in selection contains a range error. Some are due to the method itself, but the main source is taking the fragile human decisions. Providing selection tools to the company can be characterized along a continuum from meetings, request forms and reference the more traditional method, the encapsulated history, aptitude exams, valuation centers, work trials, the sophisticated psychosomatic tests, techniques and so on. Each technique has its rewards and drawbacks based on its psychological characteristics and comparative advantages of each method. A selection technique is considered valid, perhaps because of the complexity of determining its reliability and efficiency (Miyake, 2002).

In Iraqi, public sector is the major employer. Despite being the biggest employer, the recruitment and selection techniques are not up to the mark, as has been reported by the World Bank (2006). Nepotism and corruption mar the recruitment policy. World Bank (2006) highlighted that there is a need of more transparent recruitment and selection and the recruitment of employees should be tied to the future performance of an individual. BMI (2011) in their report on Iraqi oil \& gas sector, have highlighted that the Iraqi labor and investment laws requires companies to recruit Iraqi nationals. The report also highlights that the companies are required to provide skills training to their employees along with provision of incentives and allowances for enhancing the efficiency of the employees.

\subsection{Organizational Performance}

Performance is an indication of efficiency and effectiveness for business leaders through which company provides services and products. Previous studies Previous studies (Btt, 2002; Chuang \& Liao, 2010; MacDuffie, 2009; Gong et al., 2009; Chang et al., 2011; Tiwari, 2012; Aajer \& Yusot, 2013; Trehan \& Setia, 2014) have used various variables to investigate operational measures such as labour productivity (LP), product quality (PQ), organizational innovations (OI), and customer satisfaction (CS). Every measure defines how performance of a company is related to the competitors. To measure an organization's efficiency, labor productivity is utilized. Level of quality and service is measured by quality. The rate at which newly deployed service or product is measured is organizational innovation. Leaders of organizations face many different situations related to the performance of operations; this study has tried to address such issues.

The association between the performance of an organization and High Performance Work Practices (HPWP) systems are broadly assessed by Huselid (1995). On the basis of the national sample of almost one thousand companies, findings designate that these practices assert statistically and an economically considerable effect on both intermediate operational results (productivity and turnover) and long-and-short-term measures of financial performance of business. It is revealed by Katz, Kochan, and Weber (1985) that extremely effectual systems related to industrial relations, termed as those having disciplinary actions, and fewer grievances, lower absenteeism rate, an increased quality of product and direct efficiency of labor. It is also shown by Katz, Kochan, and Keefe (1987) that numerous practices of innovative work make improvements in productivity. It is found by Katz, Kochan, and Gobeille (1983) and Schuster (1983) that labor-management teams, quality circles, and quality of work life (QWL) improved productivity. A relationship between the implementation of training plans and productivity augmentation is found by Bartel (1994) and Holzer (1987) illustrated that widespread efforts intended for recruiting improved productivity. It is expressed by Guzzo, Jette, and Katzell's (1985) that socio technical system design, goal setting, and training had considerable and positive impacts over productivity.

Much research has been conducted to find relation between HRM outcomes and product quality taking samples from big businesses. In one such study, having surveyed 1,243 employees in the 64 centers on the process of 
service quality, as assessed by customer surveys; call handling time, revenues per call, and net revenues per call, Batt (2002) concluded that HRM practices emphasizing employee training, discretion, and rewards contribute to higher revenues per call, higher service quality, and higher net revenues. The extant literature on SHRM has shown that HR practices that enhance employees' abilities, motivation and advancement opportunities are associated with higher employee commitment (Gong, Law, \& Xin, 2009), lower turnover (Batt, 2002), higher productivity and quality (MacDuffie, 1995), better service performance (Chuang \& Liao, 2010), enhanced safety performance (Zacharatos, Barling, \& Iverson, 2005), and better financial performance (Huselid, 1995).

Levels of organizational innovations are highest in firms where employees encompassed high commitment levels to their managers, high trust levels in administration and high cooperation levels amongst employees. An indication was also there that lower levels of intentions of turnover assert a definite influence over service development or new product. It can be concluded from these results that firms can foster high levels of commitment to managers, high cooperation levels, and higher levels of trust in management and, to a lesser degree, low intentions of turnover amongst workers are more probable to successfully develop new services or products. Similarly, firms hoping to improve their service development or new product ought to lay its attention on enhancing trust in management, cooperation amongst employees and commitment to managers (Aragon-Correa et al., 2007).

Customer satisfaction is the degree of satisfaction provided by the goods or services of a company as measured by the number of repeat customers. It is extremely important for a business firm as they decide the fate of the business. If a company fails to satisfy their existing customers there are many other firms who would like the opportunity to win the business. The external customer satisfaction heavily depends on the satisfaction of internal customers, i.e., employees of the business firm. Therefore, employees' job satisfaction is a crucial determinant of external customer satisfaction that has a lot to do with HRM to enhance internal customer satisfaction (Chang et al., 2011). Hajer and Yusof (2013) have highlighted that in Iraq organizations are facing many challenges in managing and improving business performances mainly due to poor human resource management practices. The authors are of the opinion that there is a need for the companies to restrategise their human resource practices to increase the performance.

\subsection{Recruitment \& Selection and Firm Performance}

The fundamental reason behind recruitment is to generate a cluster of duly eligible candidates to facilitate the best candidates' selection for the organization, by means of drawing closer more and more workers to submit an application in the firm while the fundamental reason behind selection procedure is to pick the suitable candidate to fill up the range of vacant positions in the firm. As stated by Montana and Charnov (2000), recruitment and selection incorporate sourcing candidates through advertising or various different techniques screening of potential candidates by means of employing interviews and tests, the selection of candidates based upon the interviews or tests results, and on-boarding to make sure that the candidates have the ability to perform their new jobs efficiently. Recruitment and selection outline the main component of the overall resourcing stratagems of an organization, which recognizes and obtains people required in an organization to last and be successful in the short term to medium term (Elwood \& James, 1996). In addition, there is a significant and positive association between the firm's performance and recruitment and selection. A positive relationship is also found by Sang (2005) between the performance of business and recruitment and selection. Wright et al. (2005), Husien (2012), Katou and Budhwar (2006), and Ichniowski and Shaw (1999) also highlighted related positive findings between performance and recruitment and selection in Iraq, New Zealand, Finland and Canada.

According to Husien (2012), process of recruitment provides a large pool of individuals, who apply for the job vacancies with a valid and reliable selection regime, may have a significant influence over the type and quality a new employee possesses. To shape an employee's behavior and attitude, human resource policies of an organization represent important forces. Selection procedures actually determine that who is rejected and who is hired. If the policies are properly designed, it will assist in induction of right individuals who match the job specifications. Productivity increases when best candidates are inducted. Positive relation was found by Terpstra and Rozell (1993) between selection test validation, extensiveness of recruiting and use of formal selection processes and firm profits. Some researchers concluded that there is a positive relation between organizational performance and effective staffing. Similarly, Rauf (2007) also concluded that selection processes and sophisticated recruitment are positively related to labor productivity.

The following propositions are put forth based on the literature and proposed model of the study.

P1: Recruitment \& selection practices followed by organizations would have a significant relationship with the organizational performance. 
P1.1: Recruitment $\&$ selection practices followed by organizations would have a significant relationship with the labor productivity.

P1.2: Recruitment \& selection practices followed by organizations would have a significant relationship with the product quality.

P1.3: Recruitment \& selection practices followed by organizations would have a significant relationship with the organizational innovation.

P1.4: Recruitment \& selection practices followed by organizations would have a significant relationship with the customer satisfaction.

\subsection{Conceptual Framework}

Based on the literature review, a conceptual model which is assumed to be fit for firms has been developed. For the purpose of this study, labor productivity (LP), product quality (PQ) organizational innovation (OI) and customer satisfaction (CS) have been taken into consideration as operational variables to indicate organizational performance.

The conceptual framework is proposed above to explain the relationship between HRM practices and firm performance, in Iraq's oil and gas sector through a direct relationship, HRM practices (attraction and selection) have been identified on the basis of a review of the previous literature related to the subject. The model shows that the Iraqi oil and gas sector should adopt the practices of HRM (attraction and selection), which would enhance the performance of the employee and therefore the performance of the organization.

\section{Conclusion}

The prior research studies results offer several key implications for owners/managers of organizations interested in improving business performance. Effective recruitment and selection practices lead to positive increase in organizational performance. The effective use of recruitment and selection practices in firms has shown to be related to performance which represents labour productivity, product quality, organizational innovations, and customer satisfaction. Therefore, the study highlights the importance of HRM practices to achieve and sustain superior performance in changing business environment and need for an integrated approach toward formulation and implementation of HRM practices. In addition, this study was based on the literature review, a powerful relation between recruitment \& selection and organizational performance of oil and gas sector in Iraq is found. The present study has provided a model that could be used for testing the propositions outlined in the study and to empirically test the model for its validity and robustness.

It is recommended that in-depth research applied to the study of recruitment and selection practices in its relationship with organizational performance in other sectors as well as in conducting field research to figure out the relationship practices of human resource management and organizational performance in the Iraqi oil and gas to the importance of the sector and its role in the Iraqi economy and the importance of the practices of human resource management which has achieved a qualitative leap in the style of human resources management as the most important assets of the organization, a resource that can achieve a sustainable competitive advantage.

\section{Acknowledgments}

The authors would like to thank the anonymous reviewers whose constructive suggestions and corrections have improved the quality of the paper. Also the authors are thankful to the Ministry of Higher Education (MOHE), Iraq for providing the research grant. The facilities provided by the University Technology Malaysia (UTM), Johor are gratefully acknowledged.

\section{References}

Adnan, M. R., \& Izzat, K. A. A. (2012). The impact of human resource management practices on corporate performance: Empirical study in Jordanian commercial banks. African Journal of Business Management, 6(41), 10591-10595.

Al-Sabah. (2007). SME role in rebuilding economy of Iraq. Retrieved October 15, 2011, from https://tijarairaq.com/?pname $=$ open $\& \mathrm{f}=\& \mathrm{id}=1741 \&$ type $=\mathrm{html}$

Anderson, E. W., Fornell, C., \& Lehmann, D. R. (1994). Customer satisfaction, market share, and profitability: Differences between goods and services. Journal of Marketing Research, 7, 53-66.

Anthony, W. P., Kacmar, K. M., \& Perrewe, P. L. (2002). Human resources management: A strategic approach (4th ed.). Harcourt College Publisher.

Aragon-Correa, J. A., García-Morales, V. J., \& Cordón-Pozo, E. (2007). Leadership and organizational learning’s 
role on innovation and performance: Lessons from Spain. Industrial marketing management, 36(3), 349-359. http://dx.doi.org/10.1016/j.indmarman.2005.09.006

Atkinson, J., \& Storey, D. (1994). Small Firms and Employment, Employment in the Small Firm and the Labour Market. Londo: Routledge.

Bacon, N., \& Hoque, K. (2005). HRM in the SME sector: Valuable employees and coercive networks. The International Journal of Human Resource Management, 16(11), 1976-1999. http://dx.doi.org/10.1080/09585190500314706

Barber, A., Wesson, M., Roberson, Q., \& Taylor, S. (1999). A tale of two job markets: Organizational size and its effects on hiring practices and job search behaviour. Personnel Psychology, 52(4), 841-867. http://dx.doi.org/10.1111/j.1744-6570.1999.tb00182.x

Bartel, A. P. (1994). Productivity gains from the implementation of employee training programs. Industrial Relations, 33, 41-425. http://dx.doi.org/10.1111/j.1468-232X.1994.tb00349.x

Batt, R. (2002). Managing customer services: Human resource practices, quit rates, and sales growth. Academy of Management Journal, 45, 587-597. http://dx.doi.org/10.2307/3069383

BMI. (2011). Iraq’s Oil \& Gas Report. Business Monitor International, London.

Boxall, P., \& Purcell, J. (2011). Strategy and Human Resource Management (3rd ed.). New York: Palgrave Macmillan.

Cassell, C., Nadin, S., Gray, M., \& Clegg, C. (2002). Exploring human resource management practices in small and medium sized enterprises. Personnel Review, 31(6), 671-692. http://dx.doi.org/10.1108/00483480210445962

Chang, S., Gong, Y., \& Shum, C. (2011). Promoting innovation in hospitality companies through human resource management practices. International Journal of Hospitality Management, 30(4), 812-818. http://dx.doi.org/10.1016/j.ijhm.2011.01.001

Chuang, C., \& Liao, H. (2010). Strategic human resource management in service context: Taking care of business by taking care of employees and customers. Personal Psychology, 63, 153-196. http://dx.doi.org/10.1111/j.1744-6570.2009.01165.x

Delery, J. E., \& Shaw, J. D. (2001). The strategic management of people in work organizations: Review, synthesis, and extension. In G. R. Ferris (Ed.), Research in personnel and human resource management (Vol. 20, pp. 167-197). Stamford, CT: JAI. http://dx.doi.org/10.1016/s0742-7301(01)20003-6

Delery, J. E., \& Doty, D. H. (1996). Modes of theorizing in strategic human resource management: Tests of universalistic, contingency, and configurational performance predictions. Academy of Management Journal, 39, 802-835. http://dx.doi.org/10.2307/256713

Deshpande, S., \& Golhar, D. Y. (1994). HRM practices in large and small manufacturing firms: A comparative study. Journal of Small Business management, 32(2), 49-56.

Dessler, G. (2008). Human Resource Management (11th ed.). NJ: Pearson Prentice-Hall, Upper Saddle River.

Elwood., \& James A. P. (1996). Productivity gains from the implementation of employee training Programs. Industrial relations, 33(4), 411-425.

Evanschitzky, H., Sharma, A., \& Prykop, C. (2012). The role of the sales employee in securing customer satisfaction. European Journal of Marketing, 46(3/4), 489-508. http://dx.doi.org/10.1108/03090561211202576

Farnham, D. (2010). Human Resource Management in Context: Strategy, Insights and Solutions (3rd ed.). London: CIPD.

Fisher, C. D., Schoenfeldt, L. F., \& Shaw, J. B. (2006). Human Resource Management (6th ed.). Boston, MA: Houghton Mifflin.

Flanagan, \& Despanade. (1996). Top management's perceptions of changes in HRM practices after union elections in small firms. Journal of Small Business Management, 34(4), 23-34.

Fornell, C. (1992). A national customer satisfaction barometer: The Swedish experience. Journal of Marketing, January, 6-21. http://dx.doi.org/10.2307/1252129

Gebauer, H., Gustafsson, A., \& Witell, L. (2011). Competitive advantage through service differentiation by 
manufacturing companies. Journal of Business Research, 64(12), 1270-1280. http://dx.doi.org/10.1016/j.jbusres.2011.01.015

Gong, Y., Law, K. S., Chang, S., \& Xin, K. R. (2009). Human resources management and firm performance: The differential role of managerial affective and continuance commitment. Journal of Applied Psychology, 94, 263-275. http://dx.doi.org/10.1037/a0013116

Good, D. C. (1998). Gender and successful human resource decision in small business. New York, Garland publishing, Blackpool.

Gooderham, P., \& Nordhaug, O. (2011). One European Model of HRM? Cranet Empirical Contributions. Human Resource Management Review, 21, 27-36. http://dx.doi.org/10.1016/j.hrmr.2010.09.009

Greenidge, D., Alleyne, P., Parris, B., \& Grant, S. (2012). A comparative study of recruitment and training practices between small and large businesses in an emerging market economy: The case of Barbados. Journal of Small Business and Enterprise Development, 19(1), 164-182. http://dx.doi.org/10.1108/14626001211196460

Guthrie, J. P., (2001). High-involvement work practices, turnover, and productivity: Evidence from New Zealand. Academy of Management Journal, 44(1), 180-190. http://dx.doi.org/10.2307/3069345

Guzzo, R. A., Jette, R. D., \& Katzell, R. A. (1985). The effect of psychologically based intervention programs in worker productivity: A meta-analysis. Personnel Psychology, 38, 275-291. http://dx.doi.org/10.1111/j.1744-6570.1985.tb00547.x

Hajer, M. A., \& Yusof, Z. M. (2013). Building Self-confidence and Self-efficacy among Employees in the Iraqis Small and Medium Enterprises (SMES) Based on Business Process Reengineering (BPR) Tools: A Proposal New BPR Model. Management, 3(1), 45-49.

Hanna, G. F., Hammoud, M. S., \& Russo-Converso, J. A. (2014). Foreign Direct Investment in Post-Conflict Countries: The Case of Iraq's Oil and Electricity Sectors. International Journal of Energy Economics and Policy, 4(2), 137-148.

Hendrix, S. E. (n.d.). Institutional Capacity Building and Legal Reform in Iraq: Toward Innovation and Public Administration Modernization. The Law and Development Review, 6(1), 225-253.

Henman, H. G. III., \& Berkley, R. A. (1999). Applicant attraction practices and outcomes among small businesses. Journal of Small Business Management, 37(1), 53-74.

Henry, O., \& Temtime, Z. (2009). Recruitment and selection practices in SMEs: Empirical evidence from a developing country perspective. Advances in Management, 3(2), 52-58.

Holzer, H. J. (1987). Hiring procedures in the firm: Their economic determinants and outcomes. In M. M. Kleiner, R. N. Block, M. Roomkin, \& S. W. Salsburg (Eds.), Human resources and the performance of the firm. Washington, DC: BNA Press.

Huselid, A. M. (1995). The impact of human resource management practices on turnover, productivity, and corporate financial performance. Academy of Management Journal, 38(3), 635-672. http://dx.doi.org/10.2307/256741

Husien, W. A. (2012). Role of Strategic Human Resources Management on SMEs' Performance in Iraq (Master Published Thesis, Universiti Utara Malaysia, Malaysia).

Ichniowski, C., Shaw, K., \& Prennushi, G. (1999). The effects of human resource management practices on productivity: A study of steel finishing lines. American Economic Review, 87(3), 291-313.

Jeon, H., \& Choi, B. (2012). The relationship between employee satisfaction and customer satisfaction. Journal of Services Marketing, 26(5), 332-341. http://dx.doi.org/10.1108/08876041211245236

Katou, A. A., \& Budhwar, P. S. (2006). Human resource management systems and organizational performance: A test of a mediating model in the Greek manufacturing context. International Journal of Human Resource Management, 17, 1223-1253. http://dx.doi.org/10.1080/09585190600756525

Katz, H. C., Kochan T. A., \& Gobeille, K. R. (1983). Industrial relations performance, economic performance, and QWL programs: An interplant analysis. Industrial and Labor relations Review, 37, 3-17. http://dx.doi.org/10.1177/001979398303700101

Katz, H. C., Kochan T. A., \& Keefe, J. H. (1987). Industrial relations and productivity in the U.S. automobile industry. Washington, DC: Brookings Institution. 
Katz, H. C., Kochan, T. A., \& Weber, M. R. (1985). Assessing the effects of industrial relations systems and efforts to improve the quality of working life on organizational effectiveness. Academy of Management Journal, 28, 526-538. http://dx.doi.org/10.2307/256111

Kok, J. D. (2003). Human resource management within small and medium-sized enterprises. Amsterdam: Rozenberg Publishers.

Lengnick-Hall, M. L., Lengnick-Hall, C. A., Andrade, L. S., \& Drake, B. (2009). Strategic Human Resource Management: The Evolution of the Field. Human Resource Management Review, 19, 64-85. http://dx.doi.org/10.1016/j.hrmr.2009.01.002

Lockwood, N. R. (2007). Leveraging employee engagement for competitive advantage. SHRM Research Quarterly, 52(3), 1-12.

Luc, S., \& Maes, J. (2006). Linking HRM and small business performance: An examination of the impact of HRM intensity on the productivity and financial performance of small businesses. Small Business Economics, 26, 83-101. http://dx.doi.org/10.1007/s11187-004-6488-6

MacDuffie, J. P. (1995). Human resource bundles and manufacturing performance: Organizational logic and flexible production systems in the world auto industry. Industrial and Labor Relations Review, 48, 197-221. http://dx.doi.org/10.1177/001979399504800201

Marlow, S., \& Patton, D. (1993). Managing the employment relationship in the small firm: Possibilities for human resource management. International Small Business Journal, 11(4), 57-64. http://dx.doi.org/10.1177/026624269301100404

McEvoy, M. G. (1984). Small business personnel practices. Journal of Small Business Management, 22(4), 1-8.

Montan, H., \& Charnou, B. (2002). Human resource practices and firm performance of multinational corporations: Influences of country of origin. Journal of International Human Resource Management, 9 , $632-652$.

Ofori, D., \& Aryeetey, M. (2011). Recruitment and Selection Practices in Small and Medium Enterprises: International. Journal of Business Administration, 2(3), 45-60.

Opatha, H. H. D. N. P. (2010). Human resource management. Author published, Colombo.

Pfeffer, J. (1994). Competitive advantage through people: Unleashing the power of the workforce. Harvard Business School press: Boston.

Prahalad, C. K. (1983). Developing strategic capability: An agenda for top management. Human Resource Management, 22(3), 237-254. http://dx.doi.org/10.1002/hrm.3930220304

Priyanath, H. M. S. (2006). Managerial deficiencies in the small and medium enterprises (SMEs) in Sri Lanka: An empirical evidence of SMEs in the Ratnapura District. Sabaragamuwa University Journal, 6(1), 93-105.

Rauf, M. A. (2007). HRM sophistication and SME performance: A case of readymade garment manufacturers and exporters in Lahore. Pakistan Report. London: HMS.

Reichheld, E. F., \& Sasser, W. E. (1990). Zero defections: Quality comes to services. Harvard Business Review (September/October), 105-111.

Sang, C. (2005). Relationship between human resource management practices and perception of organizational Taiwan performance, roles of management style, social capital, and culture: Comparison between manufacturing firms in Cambodia and Taiwan. Taiwan: National Cheng Kung University.

Schneider, B., \& Bowen, D. E. (1985). Employee and customer perceptions of service in banks: Replication and extension. Journal of Applied Psychology, 70, 423-433. http://dx.doi.org/10.1037/0021-9010.70.3.423

Schuster, M. (1983). The impact of union-management cooperation on productivity and employment. Industrial and Labor Relations Review, 36, 415-430. http://dx.doi.org/10.1177/001979398303600307

Sekaran, U. (2005). Research Methods for Business: A Skill Building Approach. Australia: John Wiley \& Sons.

Stone, R. J. (2005). Human Resource Management (5th ed.). Australia: John Wiley \& Sons.

Syed, Z. J. W. (2012). Universalistic perspective of HRM and organizational performance: Meta-analytical study. International Bulletin of Business Administration, 13.

Tarasi, C. O., Bolton, R. N., Gustafsson, A., \& Walker, B. A. (2013). Relationship Characteristics and Cash Flow Variability Implications for Satisfaction, Loyalty, and Customer Portfolio Management. Journal of Service 
Research, 16(2), 121-137. http://dx.doi.org/10.1177/1094670512465958

Terpstra, E. D., \& Rozell, J. E. (1993). The relationship of staffing practices to organizational level measures of performance. Personnel Psychology, 46(1), 27-48. http://dx.doi.org/10.1111/j.1744-6570.1993.tb00866.x

Vargo, S. L., \& Lusch, R. F. (2008). Service-dominant logic: Continuing the evolution. Journal of the Academy of Marketing Science, 36(1), 1-10. http://dx.doi.org/10.1007/s11747-007-0069-6

Wong, C., Marshall, N., Alderman, N., \& Thwaites, A. (1997). Management training in small and medium-sized enterprises: Methodological and conceptual issues. International Journal of Human Resource Management, 8(1), 44-65. http://dx.doi.org/10.1080/09585199700000040

World Bank. (2006). Rebuilding Iraq: Economic reform and Transition. In Middle east and North Africa region, Social and Economic Development Group.

Wright, P. M., Gardner, T. M., Moynihan, L. M., \& Allen, M. R. (2005). The relationship between HR Practices and firm performance: Examining causal order. Personnel Psychology, 58(2), 409-447. http://dx.doi.org/10.1111/j.1744-6570.2005.00487.x

Zacharatos, A., Barling, J., \& Iverson, R. D. (2005). High-performance work systems and occupational safety. Journal of Applied Psychology, 90, 77-93. http://dx.doi.org/10.1037/0021-9010.90.1.77

\section{Copyrights}

Copyright for this article is retained by the author(s), with first publication rights granted to the journal.

This is an open-access article distributed under the terms and conditions of the Creative Commons Attribution license (http://creativecommons.org/licenses/by/3.0/). 